\title{
Comparing Countries for Economic Indicator Variables
}

\author{
Edward Nissan (Corresponding author) \\ Department of Political Science, International Development and International Affairs \\ The University of Southern Mississippi \\ 118 College Drive, 5108, Hattiesburg, MS39406-5108, USA \\ Tel: 601-266-4310Ｅ-mail: Edward.Nissan@usm.edu
}

Farhang Niroomand

School of Business Administration, University of Houston - Victoria

3007 N. Ben Wilson, Victoria, TX 77901, USA

Tel: 361-570-4231Ｅ-mail: NiroomandF@uhv.edu

Received: November 15, 2011

Accepted: February 2, 2012 Published: March 16, 2012

doi:10.5539/ijbm.v7n6p137

URL: http://dx.doi.org/10.5539/ijbm.v7n6p137

\begin{abstract}
The purpose of this paper is to investigate the levels of extensive (wider set of goods) and intensive (larger quantities of each good) margins, as well as price, quantity, GDP, employment and GDP per worker for 126 countries grouped by human development, region and income hierarchies. Analysis of variance and the coefficient of variation were the tools of statistical analysis. In most cases the groups of countries differ substantially between them more so than countries within the groups.
\end{abstract}

Keywords: Extensive margins, Intensive margins, Workers productivity

\section{Introduction}

Phelps (2008) describes a great transformation of business from self-finance to companies with financial freedom to operate and compete with one another. In a modern economy, doors are open for individuals to engage and develop new products and commercial innovations. Phelps explains that innovations produce uncertainties and unanticipated consequences. The costs and benefits of innovations are attained after their launch. Innovations transform jobs; cause rapid growth, disequilibria, and big swings in business; and contribute to employee engagement and intellectual development. Phelps goes on to say that in economies that resist innovation, the disadvantaged suffer from failure of inclusion. Also, entrepreneurship helps the disadvantaged by making their jobs less of a burden. Two alternatives are in practice for the inclusion of the disadvantaged. One of them suggests putting more resources into the economy, such as human capital and technology to raise output and employment. The other alternative suggests putting the available resources into innovative and general business activities through reforms of labor and company laws as well as reforms of the financial sector.

Hall and Jones (1999) tackle the issue of disparity of productivity between nations due to innovation. They give as an example the large difference in productivity per worker in the United States, being 35 times larger than in Niger. The explanation for such differences, as Phelps (2008) has pointed out, is a major challenge of economics. Production functions attribute the differences among countries to human and physical capital and productivity. For the case of the 35-fold difference in output between the United States and Niger, physical capital contributed a factor of 1.5 to income difference, and educational levels contributed a factor of 3.1. Productivity residual was 7.7 fold. Hall and Jones (1999) hypothesize that differences in capital accumulation and output per worker (productivity) are related to what they call social infrastructure, by which they mean institutions and government policies that determine the economic environment. The economic environment determines the accumulation of skills of individuals and determines the accumulation of capital by firms to produce output.

La Porta et al (1998) attribute economic performance to rules that cover protection of shareholders in corporations. Their sample of 49 countries reveals that countries practicing common law provide the strongest protection. The weakest countries providing legal protection for investors are those practicing French civil law. 
The German and Scandinavian countries are situated in the middle between the followers of common law and the civil-law countries. Furthermore, they found that when ownership is concentrated publicly, investor protection is negatively related. On a similar theme, Heckelman (2002) attributes the structure of institutions as means to evaluate economic performance, which includes concepts related to economic freedom. Here, the argument is concerned with whether bureaucrats or politicians can manage the economy better than can agents in a free market environment or vice-versa.

Hummels and Klenow (2005) looked at a nation's extensive set of economic data and examined the implications for extensive (increasing returns) exports to an alternative, intensive (national product differentiation) exports. Nissan and Niroomand (2009) utilized Hummels and Klenow data of the eight economic variables to compare countries grouped in accordance to classification provided by United Nations Development Report (UNDD 2007). The classifications were made by income as well as development categories. This research builds on the research by Hummels and Klenow (2005) and Nissan and Niroomand (2009) by incorporating the data produced for 126 countries. The purpose is to ascertain differences among and between countries grouped by human development index, geographic proximity (level of development), and income. Following this section, the paper discusses the "purpose" of the study along with the description of data, followed by "Results," and "Conclusion" sections.

\section{Purpose}

Hummels and Klenow $(2002,2005)$, henceforth (HK2002, HK2005), set out to examine a variety of economic indicator variables. First they looked at extensive exports (increasing returns) and second at intensive exports (national product differentiation). They explain that the extensive implies that an economy twice as large as another will export twice as much, but will not export a wider variety of goods. Economies have the alternative to export either a wider range of goods at lower prices or higher quality goods at higher prices. HK2005 collected a detailed set of data for 1995 covering 126 countries. The data for each country for each year include:

1) Overall Share of World Exports

2) $\mathrm{EM}=$ Extensive Export Margins

3) $\mathrm{IM}=$ Intensive Export Margins

4) $P=$ Export Price Index

5) $X=$ Export Quantity Index

6) $\mathrm{Y}=$ Average GDP Relative to the Rest of the World

7) $\mathrm{L}=$ Average Employment Relative to the Rest of the World

8) $\mathrm{Y} / \mathrm{L}=$ Average Productivity

Note that $0 \leq \mathrm{IM} \leq 1.00$ and $0 \leq \mathrm{EM} \leq 1.0$. The export price index $(\mathrm{P})$ is a measure of whether an exporter's prices are high or low relative to other prices in the same type of market. Similarly, the export quantity index (X) could be interpreted as exporter's quantities relative to other quantities in the same type of market.

HK2005, in Appendix A1 (pp. 720-722), provided for 126 countries estimates of their share of world exports (Overall), their fractions of extensive (EM) and intensive (IM) margins, and price (P) and quantity (X) indexes as discussed above. Also included in the appendix are a country's GDP relative to the rest of the world (Y), employment relative to the rest of the world (L), and GDP per worker relative to the rest-of-world GDP per worker (Y/L). Instead of using the data as given as was done by Nissan and Niroomand (2009), this paper provides estimates as compared to the United States. This is done by dividing the data for each country by the U.S. data, giving a score of " 1 " for each of the eight entries.

Using the averages as a way to compare the countries as groups, this research groups the 126 countries in accordance with the classifications provided by the United Nations Development Report (UNDP 2007) and the World Bank (2007). The classifications are done in three ways. The first is by human development, the second is by region (level of development) and the third is by income, with the purpose of finding out whether the groups of countries differ substantially for the various factors as explained in this section.

For the human development (UNDP 2007), the 126 countries are grouped according to the Human Development Index (HDI) into:

1) High: $\quad 0.800 \leq \mathrm{HDI} \leq 1.000$ (44 countries)

2) Medium: $0.500 \leq \mathrm{HDI} \leq 0.800$ (54 countries) 
3) Low: $\quad 0.300 \leq \mathrm{HDI} \leq 0.500$ (28 countries)

With the HDI, explain Anand and Ravallion (1993), the notion of development is often associated with rising incomes. Nowadays, the goal of development is the reduction of poverty and improvement in social services health and education in particular. The UNDP since 1999 has been publishing the Human Development Report (HDR) with the view that human development is "what can people do." Underdevelopment is the lack of certain capabilities. The HDI is an index constructed by incorporating three variables - longevity, knowledge and a decent standard of living.

For regional classification, the countries are grouped (World Bank 2007) into:

1) East Asia and the Pacific ( 8 countries)

2) Europe and Central Asia ( 9 countries)

3) Latin America and the Caribbean (26 countries)

4) Middle East and North Africa (7 countries)

5) South Asia (5 countries)

6) Sub-Saharan Africa (40 countries)

7) High OECD (25 countries)

8) Other High Income (8 countries)

For the income classification (World Bank 2007) the countries are grouped into

1) Low Income (41 countries)

2) Middle Income (34 countries)

3) Upper-Middle Income (20 countries)

4) High income (31 countries)

In the following, each of the 126 countries included in this study is identified by code numbers as outlined above. The statistical tools employed for analysis are the coefficient of variation and analysis of variance for each of the eight variables (Overall, EM, IM, P, X, Y, L, Y/L) by the three groupings outlined above. The coefficient of variation $(\mathrm{CV}=$ standard deviation/mean) is a measure for each group for each of the eight variables of the level of convergence or divergence among a group's members. Higher values of $\mathrm{CV}$ indicate a pulling away from the group's mean. In particular, when CV $>1.00$, the indication is a large magnitude of dispersion. Drennan and Lobo (1999), Friedman (1992), Rey and Dev (2006), and Dalgaard and Vastrup (2001), contend that a valid test for what is known as sigma convergence is the variance of a distribution, and, by implication, is the coefficient of variation also. The analysis of variance technique tests a hypothesis of equality of means by disaggregating total sum of squares (SST) into a between sum of squares (SSB) and a within sum of squares (SSW). The F-test as the ratio (MSB/MSW) where MSB and MSW are the mean squares obtained by dividing SSB and SSW by their proper degrees of freedom is used for testing the null hypothesis of equality of means.

\section{Results}

Table 1 provides the details for the eight variables for each of the 126 countries using the United States as a reference. $\mathrm{C} 1, \mathrm{C} 2$, and $\mathrm{C} 3$ identify a country for its place in accordance to HDI, region, and income classification as explained earlier. For Albania, the corresponding three codes $(2,2,2$,$) indicate that Albania is situated in the$ medium group of the 54 countries of the HDI, is situated among the nine countries of Europe and Central Asia and is among the 54 middle income countries. To give an idea of the entries of Table 1, the means for all the 126 countries tell us that the average share of the 126 countries of nominal exports as a ratio of nominal world exports as compared to the United States is 0.0434 . The extensive (EM) and the intensive (IM) margins are, respectively, 0.2501 and 0.0880 , indicating that on average there is more trade in a common set of goods as compared to specialized goods. That is, the extensive margin is almost three times the intensive margin. The average GDP relative to the rest of the world $(\mathrm{Y})$ and average employment relative to the rest of the world $(\mathrm{L})$ as compared to the Unites States are, respectively, 0.0311 and 0.1567 .

The United Kingdom accounts for 0.1067 as its share to world exports (Overall), as compared to the United States with 0.8382 for extensive (EM) and 0.1272 for intensive (IM) margins. For the price and quantity at 1.0928 and 0.1164, the indication is that the UK ships small quantities of specialized categories of goods at relatively high prices in contrast to the United States, for instance, with $\mathrm{P}=1.000$ and $\mathrm{X}=1.000$. UK's relative GDP (Y) to World GDP as compared to the United States is 0.1243 as compared to the United States at 1.000 . 
However, UK's employment relative to rest of the world is 0.2071 as compared to the United States at 1.000, which gives the corresponding worker productivity (Y/L) of $0.5992(0.1243 / 0.5992)$.

Table 2 provides descriptive statistics for the mean (Panel A) and the coefficient of variation (Panel B) for the 126 countries grouped by HDI classification for the eight (Overall, EM, IM, P, X, Y, L, Y/L) variables as explained in the "Purpose" section. For the "Overall" variable, which denotes the average of each group's share of world exports, the high HDI group, comprising 44 countries, registered 0.0965 in contrast to an average of 0.0025 for the 28 low HDI countries, a ratio of $0.0965 / 0.0025=38.6$ in terms of the United States as a reference. This implies that, on average, the high HDI share of world exports is almost 39 times as large as the low HDI group, and it is $4.53(0.0965 / 0.0213)$ times as large on average compared to the medium HDI group. The average share of exports for the 126 countries combined is 0.0434 .

For EM (the extensive margin) for exports, the average fraction for trade for high HDI countries is substantial at 0.4597 , compared to 0.1829 for the medium HDI countries, which is more than two-fold. For the low HDI countries, at 0.0504 , this share is again too small compared to the two other groups. Similar differences are observed for the IM (intensive margin). It is of interest to note here the smaller magnitudes of IM as compared to EM, implying that most exports around the world consist of a broader set of goods to more markets rather than shipments of larger values of a common set of goods.

For the price $\mathrm{P}$, and the quantity X, the high HDI group stands out at 0.8808 and 0.1572 as compared to the medium HDI and low HDI. Note that, as the high HDI at $\mathrm{Y}=0.0588$ is 2.5 times larger than the medium HDI group $(0.0588 / 0.0237)$ and 39.2 times larger than the low HDI group $(0.0588 / 0.0015)$.

For employment relative to the rest of the world (L), the medium HDI countries capture a large average at 0.2664, while the difference between high HDI and low HDI countries is somewhat minor. Dividing the GDP, Y, by $\mathrm{L}$, as an estimate for productivity (Y/L), the high HDI group has magnitudes of 0.5352 as compared to 0.1634 for the medium HDI and, 0.0355 for the low HDI group. The respective ratios are 3.28 and 15.1.

The coefficient of variation (CV) for the three groups by HDI for the eight variables is shown in panel (B). CV tells whether the individual members of a group depart significantly from the group's mean. The indication from Panel (B) is that for Overall, with values of $\mathrm{CV}<1.00$, for most groups there is significant convergence, implying small disparities among them.

For EM, the low HDI group $C V=1.06$. For IM, the medium HDI group stands out at $C V=1.07$. For all the 126 combined at $\mathrm{CV}=0.96$, the indication is convergence. However, for the price $\mathrm{P}$, the $\mathrm{CV}$ within all countries seems to be major at $\mathrm{CV}=2.93$. For the high HDI, $\mathrm{CV}=2.91$. For medium HDI, $\mathrm{CV}=3.03$ and $\mathrm{CV}=6.54$ for low HDI. For the quantity $\mathrm{X}$, the low HDI group has $\mathrm{CV}>1.00$, indicating wide dispersion.

For GDP (Y) and employment (L), with no exception $\mathrm{CV}<1.00$, implying small dispersions among the member countries of the groups. For $\mathrm{Y} / \mathrm{L}$, there seems to be large dispersions among the member countries of each group to that group's average at $\mathrm{CV}=2.60$ for high HDI, $\mathrm{CV}=1.87$ for medium HDI and $\mathrm{CV}=2.22$ for low HDI.

Table 3 and Table 4, similar to Table 1, display the means in Panel (A) and the coefficient of Variation in Panel (B) for the eight variables. This time, the 126 countries are grouped by (region) geographic proximity (Table 3 ), and income (Table 4). The results have similar interpretations to those found in Table 1.

Table 5 provides the results of the analysis of variance for testing equality of means by HDI category, Panel (A); region, Panel (B); and income, Panel (C). With the exception of variable $\mathrm{L}$ among the eight variables (Panels A and C), the test of hypothesis of equality is rejected at $p=0.000$. For $L$ in Panel (A), $p=0.326$ and in Panel (C), $\mathrm{p}=0.500$. The most significant difference between groups is for the productivity variable $\mathrm{Y} / \mathrm{L}$ at $\mathrm{F}=144.45$ in Panel (A), F=73.11 in Panel (B) and F=274.62 in Panel (C). One anticipates that differences in human development, region and income are due to the productivity among the nations in each group.

\section{Conclusion}

This paper, through the use of data on eight major economic indicator variables for 126 countries supplied by HK2005, aligned the countries by HDI, region and income classifications. The dividing lines for HDI were in accordance with the classifications provided by UNDP (2007), and the dividing lines for region and income classifications were provided by the World Bank (2007). The aim of the paper was to probe whether the divisions so obtained can differentiate the groups of countries for their economic performance. Note that the data supplied by HK2005 were converted into U.S. reference by dividing the entries of a country by the comparable U.S. entries. All comparisons, therefore, are in relation to the United States. Among the noted findings is that richer countries grouped by HDI, income and region differ substantially with the exception of Labor (L) variable when countries are grouped by HDI and income. This research was a further look at what Nissan and Niroomand 
(2009) have done using the same statistical methods of the coefficient of variation and the analysis of variance for analysis. However it differs in two different procedures. The first is the transformation of data provided by HK 2005 by making it relative to the US. The second is the use of different ways of aggregating the countries into groups in accordance to classifications provided by UNDP (2007) and World Bank (2007).

\section{References}

Anand, S., \& Ravallion, M. (1993). Human development in poor countries: On the role of private incomes and public services. Journal of Economic Perspectives, 7, 133-150.

Dalgaard, C., \& Vastrup, J. (2001). On the measurement of 6 -convergence. Economic Letters, 70, 283-287. http://dx.doi.org/10.1016/S0165-1765(00)00368-2

Drennan, M. P., \& Lobo, J. (1999). A simple test for convergence of metropolitan income in the United States. Journal of Urban Economics, 46, 350-359. http://dx.doi.org/10.1006/juec.1998.2126

Friedman, M. (1992). Do old fallacies ever die? Journal of Economic Literature, 30, 2129-2132.

Hall, R. E., \& Jones, C. I. (1999). Why do some countries produce so much more output per worker than others? The Quarterly Journal of Economics, 114, 83-116. http://dx.doi.org/10.1162/003355399555954

Heckelman, J. C. (2002). On the measurement of comparative economic freedom across countries. International Journal of Business and Economics, 1, 251-261.

Hummels, D., \& Klenow, P. J. (2002). The variety and quality of a nation's trade. NBER Working Paper (No. 8712).

Hummels, D., \& Klenow, P. J. (2005). The variety and quality of a nation's exports. The American Economic Review, 95, 704-723. http://dx.doi.org/10.1257/0002828054201396

La Porta, R., Lopez-de-Silanes, F., Chleifer, A., \& Vishny, R. W. (1998). Law and finance. Journal of Political Economy, 106, 1113-1155. http://dx.doi.org/10.1086/250042

Nissan, E., \& Niroomand, F. (2009). Geographic and income anatomy of international experts. Journal of Economic Studies, 36, 5-16. http://dx.doi.org/10.1108/01443580910923777

Phelps, E. S. (2008). Microeconomics for a modern economy. The American Economist, LII, 3-22.

Rey, S. J., \& Dev, B. (2006). $\sigma$-convergence in the presence of spatial effects. Papers in Regional Science, 85, 217-234. http://dx.doi.org/10.1111/j.1435-5957.2006.00083.x

UNDP. (2007). Human development report. The United Nations Development Programme. New York, NY.

World Bank. (2007). World development report 2008: Agriculture for development. The World Bank, Washington, D C. 
Table 1. Economic Performance Variables by Country (Reference U.S.)

\begin{tabular}{|c|c|c|c|c|c|c|c|c|c|c|c|}
\hline Country & $\mathrm{C} 1$ & $\mathrm{C} 2$ & $\mathrm{C} 3$ & Overall & EM & IM & $P$ & $\mathrm{X}$ & $\bar{Y}$ & $\mathrm{~L}$ & $\mathrm{Y} / \mathrm{L}$ \\
\hline Albania & 2 & 2 & 2 & 0.0005 & 0.1042 & 0.0053 & 0.4898 & 0.0112 & 0.0010 & 0.0101 & 0.0983 \\
\hline Angola & 3 & 6 & 1 & 0.0040 & 0.0956 & 0.0415 & 0.6959 & 0.0600 & 0.0014 & 0.0370 & 0.0387 \\
\hline Argentina & 1 & 3 & 3 & 0.0583 & 0.3845 & 0.1514 & 0.7582 & 0.1996 & 0.0377 & 0.1027 & 0.3669 \\
\hline Australia & 1 & 7 & 4 & 0.0673 & 0.5893 & 0.1143 & 0.7707 & 0.1484 & 0.0426 & 0.0640 & 0.6748 \\
\hline Austria & 1 & 7 & 4 & 0.0462 & 0.5486 & 0.0842 & 1.0074 & 0.0836 & 0.0178 & 0.0269 & 0.6670 \\
\hline Bangladesh & 2 & 5 & 1 & 0.0067 & 0.0864 & 0.0775 & 0.5554 & 0.1396 & 0.0184 & 0.2071 & 0.0893 \\
\hline Barbados & 1 & 3 & 3 & 0.0003 & 0.0159 & 0.0186 & 0.7142 & 0.0260 & 0.0004 & 0.0017 & 0.4145 \\
\hline Belgium & 1 & 7 & 4 & 0.0383 & 0.5150 & 0.0742 & 1.1199 & 0.0664 & 0.0223 & 0.0303 & 0.7438 \\
\hline Belize & 2 & 3 & 3 & 0.0004 & 0.0237 & 0.0153 & 0.7299 & 0.0212 & 0.0001 & 0.0000 & 0.2782 \\
\hline Benin & 3 & 6 & 1 & 0.0004 & 0.0264 & 0.0130 & 0.5487 & 0.0240 & 0.0006 & 0.0185 & 0.0325 \\
\hline Bolivia & 2 & 3 & 2 & 0.0020 & 0.0689 & 0.0289 & 0.4279 & 0.0676 & 0.0020 & 0.0202 & 0.0979 \\
\hline Botswana & 2 & 6 & 3 & 0.0002 & 0.0339 & 0.0047 & 0.6129 & 0.0076 & 0.0009 & 0.0034 & 0.2585 \\
\hline Brazil & 2 & 3 & 2 & 0.0715 & 0.5140 & 0.1390 & 0.6707 & 0.2076 & 0.1164 & 0.4226 & 0.2748 \\
\hline Bulgaria & 1 & 2 & 2 & 0.0103 & 0.3910 & 0.0265 & 0.5228 & 0.0504 & 0.0059 & 0.0286 & 0.2062 \\
\hline Burkina Faso & 3 & 6 & 1 & 0.0003 & 0.0189 & 0.0177 & 0.8712 & 0.0204 & 0.0009 & 0.0337 & 0.0266 \\
\hline Cameroon & 3 & 6 & 1 & 0.0060 & 0.1344 & 0.0445 & 0.6123 & 0.0728 & 0.0026 & 0.0455 & 0.0555 \\
\hline Canada & 1 & 7 & 4 & 0.3912 & 0.9031 & 0.4333 & 0.9695 & 0.4468 & 0.0718 & 0.1061 & 0.6738 \\
\hline Cape Verde Is. & 2 & 6 & 2 & 0.0000 & 0.0104 & 0.0038 & 0.9228 & 0.0044 & 0.0001 & 0.0017 & 0.1221 \\
\hline Central Afr.R. & 3 & 6 & 1 & 0.0002 & 0.0197 & 0.0121 & 0.5430 & 0.0224 & 0.0004 & 0.0118 & 0.0339 \\
\hline Chad & 3 & 6 & 1 & 0.0004 & 0.0021 & 0.1832 & 0.7017 & 0.2612 & 0.0006 & 0.0168 & 0.0380 \\
\hline Chile & 1 & 3 & 2 & 0.0231 & 0.1787 & 0.1293 & 0.6314 & 0.2048 & 0.0127 & 0.0387 & 0.3251 \\
\hline China & 2 & 1 & 2 & 0.3015 & 0.7722 & 0.3906 & 0.4143 & 0.9424 & 0.3936 & 7.4226 & 0.0530 \\
\hline Colombia & 2 & 3 & 2 & 0.0250 & 0.2518 & 0.0993 & 0.6992 & 0.1420 & 0.0222 & 0.1246 & 0.1780 \\
\hline Comoros & 2 & 6 & 1 & 0.0000 & 0.0003 & 0.0745 & 1.9940 & 0.0372 & 0.0001 & 0.0017 & 0.0551 \\
\hline Congo & 2 & 6 & 1 & 0.0026 & 0.1056 & 0.0242 & 0.4368 & 0.0552 & 0.0005 & 0.0084 & 0.0529 \\
\hline Costa Rica & 1 & 3 & 3 & 0.0089 & 0.1419 & 0.0627 & 0.7313 & 0.0860 & 0.0019 & 0.0084 & 0.2035 \\
\hline Cyprus & 1 & 8 & 4 & 0.0024 & 0.2104 & 0.0112 & 0.7888 & 0.0144 & 0.0012 & 0.0017 & 0.5118 \\
\hline Denmark & 1 & 7 & 4 & 0.0276 & 0.3899 & 0.0707 & 1.0699 & 0.0660 & 0.0130 & 0.0202 & 0.6565 \\
\hline Dominica & 2 & 3 & 3 & 0.0001 & 0.0120 & 0.0065 & 0.7027 & 0.0092 & 0.0000 & 0.0000 & 0.2331 \\
\hline Dominican Rep. & 2 & 3 & 2 & 0.0113 & 0.1618 & 0.0698 & 0.7896 & 0.0884 & 0.0030 & 0.0168 & 0.1749 \\
\hline Ecuador & 2 & 3 & 2 & 0.0094 & 0.1272 & 0.0736 & 0.6593 & 0.1120 & 0.0046 & 0.0253 & 0.1879 \\
\hline Egypt & 2 & 4 & 2 & 0.0125 & 0.2697 & 0.0462 & 0.5183 & 0.0896 & 0.0221 & 0.1212 & 0.1821 \\
\hline El Salvador & 2 & 3 & 2 & 0.0058 & 0.1112 & 0.0524 & 0.6902 & 0.0760 & 0.0025 & 0.0118 & 0.1978 \\
\hline Ethiopia & 3 & 6 & 1 & 0.0012 & 0.0227 & 0.0527 & 0.7436 & 0.0708 & 0.0031 & 0.1751 & 0.0178 \\
\hline Fiji & 2 & 1 & 2 & 0.0013 & 0.0329 & 0.0406 & 0.7931 & 0.0512 & 0.0004 & 0.0017 & 0.2277 \\
\hline Finland & 1 & 7 & 4 & 0.0242 & 0.3272 & 0.0739 & 1.1864 & 0.0624 & 0.0100 & 0.0185 & 0.5649 \\
\hline France & 1 & 7 & 4 & 0.1123 & 0.7318 & 0.1535 & 1.2713 & 0.1208 & 0.1293 & 0.1902 & 0.6793 \\
\hline Gabon & 2 & 6 & 3 & 0.0053 & 0.0919 & 0.0571 & 0.6403 & 0.0892 & 0.0010 & 0.0034 & 0.2682 \\
\hline Gambia & 3 & 6 & 1 & 0.0001 & 0.0061 & 0.0127 & 0.6344 & 0.0200 & 0.0001 & 0.0034 & 0.0341 \\
\hline Germany & 1 & 7 & 4 & 0.2784 & 0.8622 & 0.3228 & 1.1802 & 0.2736 & 0.1890 & 0.2912 & 0.6499 \\
\hline Ghana & 2 & 6 & 1 & 0.0038 & 0.0697 & 0.0548 & 0.7534 & 0.0724 & 0.0023 & 0.0589 & 0.0389 \\
\hline Greece & 1 & 7 & 4 & 0.0035 & 0.1309 & 0.0268 & 0.4996 & 0.0536 & 0.0137 & 0.0303 & 0.4534 \\
\hline Grenada & 2 & 3 & 3 & 0.0000 & 0.0065 & 0.0062 & 0.6681 & 0.0092 & 0.0000 & 0.0000 & 0.1605 \\
\hline Guatemala & 2 & 3 & 2 & 0.0100 & 0.1709 & 0.0586 & 0.4278 & 0.1368 & 0.0039 & 0.0202 & 0.1947 \\
\hline Guinea & 3 & 6 & 1 & 0.0012 & 0.0372 & 0.0318 & 0.4973 & 0.0640 & 0.0018 & 0.0219 & 0.0806 \\
\hline
\end{tabular}


Table 1 Continued

\begin{tabular}{|c|c|c|c|c|c|c|c|c|c|c|c|}
\hline Country & $\mathrm{C} 1$ & $\mathrm{C} 2$ & $\mathrm{C} 3$ & Overall & EM & IM & $\mathrm{P}$ & $X$ & $\mathrm{Y}$ & $\mathrm{L}$ & $\mathrm{Y} / \mathrm{L}$ \\
\hline Guinea-Biss & 3 & 6 & 1 & 0.0001 & 0.0112 & 0.0109 & 0.6875 & 0.0156 & 0.0001 & 0.0034 & 0.0249 \\
\hline Guyana & 2 & 6 & 2 & 0.0009 & 0.0254 & 0.0345 & 0.5493 & 0.0628 & 0.0002 & 0.0017 & 0.1058 \\
\hline Haiti & 3 & 3 & 1 & 0.0005 & 0.0650 & 0.0080 & 0.6579 & 0.0124 & 0.0011 & 0.0219 & 0.0515 \\
\hline Honduras & 2 & 3 & 2 & 0.0061 & 0.0979 & 0.0619 & 0.6857 & 0.0104 & 0.0012 & 0.0118 & 0.0982 \\
\hline Hong Kong & 1 & 8 & 4 & 0.0621 & 0.6198 & 0.1001 & 0.5815 & 0.1720 & 0.0166 & 0.0219 & 0.7562 \\
\hline Hungary & 1 & 2 & 3 & 0.0390 & 0.5754 & 0.0677 & 0.6439 & 0.1052 & 0.0093 & 0.0286 & 0.3160 \\
\hline Iceland & 1 & 7 & 4 & 0.0046 & 0.0595 & 0.0778 & 0.7770 & 0.1000 & 0.0006 & 0.0017 & 0.5531 \\
\hline India & 2 & 5 & 1 & 0.0377 & 0.4899 & 0.0769 & 0.5506 & 0.1396 & 0.2032 & 3.0337 & 0.0670 \\
\hline Indonesia & 2 & 1 & 2 & 0.0618 & 0.4945 & 0.1249 & 0.6313 & 0.1980 & 0.0754 & 0.5572 & 0.1354 \\
\hline Iran & 2 & 4 & 2 & 0.0359 & 0.1838 & 0.1950 & 0.6872 & 0.2840 & 0.0311 & 0.1246 & 0.2491 \\
\hline Ireland & 1 & 7 & 4 & 0.0168 & 0.2799 & 0.0601 & 1.9811 & 0.0304 & 0.0065 & 0.0101 & 0.6622 \\
\hline Israel & 1 & 8 & 4 & 0.0227 & 0.4416 & 0.0515 & 1.2791 & 0.0404 & 0.0094 & 0.0152 & 0.6355 \\
\hline Italy & 1 & 7 & 4 & 0.1075 & 0.7191 & 0.1496 & 1.0842 & 0.1380 & 0.1258 & 0.1650 & 0.7660 \\
\hline Ivory Coast & 3 & 6 & 1 & 0.0111 & 0.1889 & 0.0586 & 0.7321 & 0.0800 & 0.0027 & 0.0370 & 0.0721 \\
\hline Jamaica & 2 & 3 & 2 & 0.0037 & 0.0705 & 0.0518 & 0.6880 & 0.0756 & 0.0010 & 0.0084 & 0.1136 \\
\hline Japan & 1 & 7 & 4 & 0.6539 & 0.7943 & 0.8233 & 1.1590 & 0.7100 & 0.3341 & 0.5825 & 0.5732 \\
\hline Jordan & 2 & 4 & 2 & 0.0012 & 0.0691 & 0.0168 & 0.5279 & 0.0316 & 0.0016 & 0.0067 & 0.2400 \\
\hline Kenya & 3 & 6 & 1 & 0.0037 & 0.0765 & 0.0489 & 0.7141 & 0.0684 & 0.0036 & 0.0943 & 0.0377 \\
\hline Lesotho & 3 & 6 & 1 & 0.0003 & 0.0244 & 0.0109 & 0.5479 & 0.0200 & 0.0003 & 0.0067 & 0.0426 \\
\hline Luxembourg & 1 & 7 & 4 & 0.0010 & 0.0319 & 0.0324 & 0.9711 & 0.0338 & 0.0015 & 0.0017 & 1.1820 \\
\hline Macedonia & 2 & 2 & 2 & 0.0031 & 0.1656 & 0.0186 & 0.6414 & 0.0288 & 0.0009 & 0.0067 & 0.1548 \\
\hline Madagascar & 3 & 6 & 1 & 0.0020 & 0.0769 & 0.0259 & 0.7799 & 0.0332 & 0.0011 & 0.0404 & 0.0279 \\
\hline Malawi & 3 & 6 & 1 & 0.0008 & 0.0229 & 0.0333 & 0.6417 & 0.0520 & 0.0007 & 0.0303 & 0.0233 \\
\hline Malaysia & 2 & 1 & 3 & 0.1036 & 0.5963 & 0.1738 & 0.5619 & 0.3092 & 0.0188 & 0.0522 & 0.3670 \\
\hline Mali & 3 & 6 & 1 & 0.0003 & 0.0123 & 0.0239 & 0.6785 & 0.0348 & 0.0008 & 0.0337 & 0.0249 \\
\hline Malta & 1 & 8 & 4 & 0.0039 & 0.1927 & 0.0200 & 0.7414 & 0.0272 & 0.0005 & 0.0017 & 0.5062 \\
\hline Mauritania & 3 & 6 & 1 & 0.0017 & 0.0207 & 0.0834 & 0.5755 & 0.1448 & 0.0003 & 0.0084 & 0.0388 \\
\hline Mauritius & 2 & 6 & 3 & 0.0036 & 0.0778 & 0.0471 & 0.9098 & 0.0516 & 0.0013 & 0.0034 & 0.3700 \\
\hline Mexico & 1 & 3 & 3 & 0.1749 & 0.8158 & 0.2144 & 0.7078 & 0.3028 & 0.0695 & 0.2239 & 0.3112 \\
\hline Morocco & 2 & 4 & 2 & 0.0227 & 0.2831 & 0.0801 & 0.7970 & 0.1004 & 0.0095 & 0.0589 & 0.1593 \\
\hline Mozambique & 3 & 6 & 1 & 0.0005 & 0.0216 & 0.0224 & 0.7937 & 0.0280 & 0.0013 & 0.0556 & 0.0243 \\
\hline Myanmar & 2 & 1 & 1 & 0.0009 & 0.0196 & 0.0457 & 0.8660 & 0.0528 & 0.0004 & 0.0219 & 0.0197 \\
\hline Namibia & 2 & 6 & 2 & 0.0022 & 0.0525 & 0.0427 & 0.8975 & 0.0476 & 0.0007 & 0.0034 & 0.2176 \\
\hline Nepal & 2 & 5 & 1 & 0.0008 & 0.0401 & 0.0191 & 0.6113 & 0.3120 & 0.0028 & 0.0623 & 0.0438 \\
\hline Netherlands & 1 & 7 & 4 & 0.0454 & 0.6326 & 0.0719 & 0.9625 & 0.0744 & 0.0341 & 0.0505 & 0.6652 \\
\hline New Zealand & 1 & 7 & 4 & 0.0223 & 0.2540 & 0.0875 & 0.8184 & 0.1072 & 0.0067 & 0.0118 & 0.5463 \\
\hline Nicaragua & 2 & 3 & 1 & 0.0012 & 0.0551 & 0.0224 & 0.6899 & 0.0324 & 0.0001 & 0.0101 & 0.0863 \\
\hline Niger & 3 & 6 & 1 & 0.0005 & 0.0498 & 0.0091 & 0.7843 & 0.0116 & 0.0008 & 0.0320 & 0.0252 \\
\hline Nigeria & 3 & 6 & 1 & 0.0243 & 0.1581 & 0.1538 & 0.7813 & 0.1968 & 0.0108 & 0.3855 & 0.0281 \\
\hline Norway & 1 & 7 & 4 & 0.1317 & 0.6667 & 0.1973 & 0.7843 & 0.2516 & 0.0109 & 0.0152 & 0.7127 \\
\hline Pakistan & 2 & 5 & 1 & 0.0104 & 0.1403 & 0.0742 & 0.6059 & 0.1224 & 0.0245 & 0.2458 & 0.1000 \\
\hline Panama & 1 & 3 & 3 & 0.0068 & 0.1237 & 0.0554 & 0.6875 & 0.0808 & 0.0015 & 0.0067 & 0.2242 \\
\hline Papua New Guin & 2 & 1 & 1 & 0.0052 & 0.0405 & 0.1281 & 0.7771 & 0.1648 & 0.0016 & 0.0152 & 0.1113 \\
\hline Paraguay & 2 & 3 & 2 & 0.0048 & 0.0477 & 0.1007 & 0.6020 & 0.1672 & 0.0027 & 0.0152 & 0.1807 \\
\hline Peru & 2 & 3 & 2 & 0.0073 & 0.1175 & 0.0624 & 0.4204 & 0.1484 & 0.0109 & 0.0724 & 0.1508 \\
\hline Philippines & 2 & 1 & 2 & 0.0242 & 0.3879 & 0.0622 & 0.6565 & 0.0948 & 0.0224 & 0.2020 & 0.1111 \\
\hline
\end{tabular}


Table 1 Continued

\begin{tabular}{|c|c|c|c|c|c|c|c|c|c|c|c|}
\hline Country & $\mathrm{C} 1$ & $\mathrm{C} 2$ & $\mathrm{C} 3$ & Overall & EM & IM & $\mathrm{P}$ & $\mathrm{X}$ & $\mathrm{Y}$ & $\mathrm{L}$ & $\mathrm{Y} / \mathrm{L}$ \\
\hline Poland & 1 & 2 & 3 & 0.0600 & 0.6355 & 0.0946 & 0.4975 & 0.1900 & 0.0296 & 0.1229 & 0.2420 \\
\hline Portugal & 1 & 7 & 4 & 0.0060 & 0.2544 & 0.0236 & 0.5733 & 0.0408 & 0.0135 & 0.0320 & 0.4287 \\
\hline Romania & 2 & 2 & 2 & 0.0151 & 0.3880 & 0.0389 & 0.4998 & 0.0776 & 0.0113 & 0.0808 & 0.1404 \\
\hline Russia & 2 & 2 & 2 & 0.0953 & 0.5172 & 0.1844 & 0.5257 & 0.3504 & 0.1147 & 0.5320 & 0.2154 \\
\hline Rwanda & 3 & 6 & 1 & 0.0002 & 0.0145 & 0.0112 & 0.7110 & 0.0156 & 0.0005 & 0.0219 & 0.0222 \\
\hline Senegal & 3 & 6 & 1 & 0.0018 & 0.0508 & 0.0359 & 0.6512 & 0.0552 & 0.0013 & 0.0286 & 0.0450 \\
\hline Seychelles & 1 & 6 & 3 & 0.0001 & 0.0059 & 0.0189 & 0.6772 & 0.0280 & 0.0001 & 0.0000 & 0.3159 \\
\hline Sierra Leone & 3 & 6 & 1 & 0.0002 & 0.0219 & 0.0068 & 0.7190 & 0.0096 & 0.0004 & 0.0118 & 0.0362 \\
\hline Singapore & 1 & 7 & 4 & 0.1015 & 0.6232 & 0.1629 & 0.9018 & 0.1808 & 0.0084 & 0.0152 & 0.5794 \\
\hline Slovak Rep & 1 & 2 & 3 & 0.0384 & 0.5312 & 0.0722 & 0.5311 & 0.1360 & 0.0053 & 0.0185 & 0.2976 \\
\hline Slovenia & 1 & 8 & 4 & 0.0247 & 0.4792 & 0.0515 & 0.6665 & 0.0776 & 0.0026 & 0.0067 & 0.4000 \\
\hline South Africa & 2 & 6 & 2 & 0.0412 & 0.4413 & 0.0934 & 0.6785 & 0.1376 & 0.0298 & 0.0943 & 0.3159 \\
\hline South Korea & 1 & 7 & 4 & 0.1338 & 0.7104 & 0.1882 & 0.7685 & 0.2448 & 0.0651 & 0.1347 & 0.4853 \\
\hline Spain & 1 & 7 & 4 & 0.0284 & 0.4640 & 0.0613 & 0.9420 & 0.0648 & 0.0682 & 0.1111 & 0.6126 \\
\hline Sri Lanka & 2 & 5 & 2 & 0.0047 & 0.1393 & 0.0336 & 0.7333 & 0.0456 & 0.0058 & 0.0539 & 0.1087 \\
\hline St. Vincent & 2 & 3 & 3 & 0.0002 & 0.0075 & 0.0259 & 0.7391 & 0.0352 & 0.0001 & 0.0000 & 0.2181 \\
\hline Sweden & 1 & 7 & 4 & 0.0514 & 0.5266 & 0.0978 & 1.2639 & 0.0772 & 0.0192 & 0.0320 & 0.5897 \\
\hline Switzerla & 1 & 7 & 4 & 0.1548 & 0.6974 & 0.2221 & 1.5367 & 0.1444 & 0.0182 & 0.0269 & 0.6562 \\
\hline Syria & 2 & 4 & 2 & 0 . & 0.15 & 0.0 & 0.6 & 76 & 58 & 53 & 2360 \\
\hline Taiwan & 1 & 8 & 4 & 0.1489 & 0.7032 & 0.2118 & 0.5712 & 0.3708 & 0.0331 & 0.0657 & 0.5011 \\
\hline Tanzania & 3 & 6 & 1 & 0.0012 & 0.0543 & 0.0218 & 0.6834 & 0.0320 & 0.0014 & 0.0993 & 0.0145 \\
\hline Thailand & 2 & 1 & 2 & 0.0576 & 0.5499 & 0.1049 & 0.6160 & 0.1700 & 0.0425 & 0.2256 & 0.1882 \\
\hline Togo & 2 & 6 & 1 & 0.0003 & 0.0268 & 0.0118 & 0.4577 & 0.0260 & 0.0004 & 0.0118 & 0.0321 \\
\hline Trinidad & 1 & 3 & 3 & 0.0043 & 0.0929 & 0.0465 & 0.5711 & 0.0812 & 0.0012 & 0.0034 & 0.3478 \\
\hline Tunisia & 2 & 4 & 2 & 0.0207 & 0.3689 & 0.0560 & 0.8184 & 0.0684 & 0.0052 & 0.0202 & 0.2479 \\
\hline Turkey & 2 & 2 & 2 & 0.0468 & 0.4486 & 0.1043 & 0.6901 & 0.1512 & 0.0398 & 0.1919 & 0.2082 \\
\hline United Kingdom & 1 & 7 & 4 & 0.1067 & 0.8382 & 0.1272 & 1.0928 & 0.1164 & 0.1243 & 0.2071 & 0.5992 \\
\hline United States & 1 & 7 & 4 & 1.0000 & 1.0000 & 1.0000 & 1.0000 & 1.0000 & 1.0000 & 1.0000 & 1.0000 \\
\hline Uganda & 2 & 6 & 1 & 0.0017 & 0.0274 & 0.0622 & 0.6569 & 0.0948 & 0.0016 & 0.0657 & 0.0245 \\
\hline Uruguay & 1 & 3 & 3 & 0.0009 & 0.1378 & 0.0669 & 0.7603 & 0.0880 & 0.0030 & 0.0101 & 0.2905 \\
\hline Venezuela & 2 & 3 & 3 & 0.0446 & 0.2273 & 0.1965 & 0.6054 & 0.3244 & 0.0163 & 0.0539 & 0.3018 \\
\hline Yemen & 3 & 4 & 1 & 0.0015 & 0.0481 & 0.0315 & 0.6180 & 0.0508 & 0.0014 & 0.0269 & 0.0525 \\
\hline Zaire & 3 & 6 & 1 & 0.0043 & 0.1029 & 0.0412 & 0.3968 & 0.1040 & 0.0015 & 0.1532 & 0.0096 \\
\hline Zambia & 3 & 6 & 1 & 0.0013 & 0.0277 & 0.0465 & 0.7324 & 0.0636 & 0.0008 & 0.0219 & 0.0359 \\
\hline Zimbabwe & 2 & 6 & 1 & 0.0039 & 0.1059 & 0.0371 & 0.7395 & 0.0500 & 0.0030 & 0.0370 & 0.0805 \\
\hline Mean & & & & 0.0434 & 0.2501 & 0.0880 & 0.7450 & 0.1191 & 0.0311 & 0.1567 & 0.2648 \\
\hline Standard Deviation & & & & 0.1182 & 0.2603 & 0.1278 & 0.2544 & 0.1493 & 0.1035 & 0.7167 & 0.2446 \\
\hline \multicolumn{12}{|c|}{ Notes: C1 HDI: 1. High, 2. Medium, 3. Low. } \\
\hline \multicolumn{12}{|c|}{ C2 Region: 1. East Asia and Pacific, 2. Europe and Central Asia, 3.Latin America and the Caribbean, } \\
\hline \multicolumn{12}{|c|}{ 4. Middle East and North Africa, 5. South Asia, 6. Sub-S } \\
\hline \multicolumn{12}{|c|}{ C3 Income: 1. Low, 2. Middle, 3. Upper Middle, 4. High. } \\
\hline \multicolumn{12}{|c|}{$\mathrm{EM}=$ extensive margin, $\mathrm{IM}=$ intensive margin, $\mathrm{P}=$ price, $\mathrm{X}=$ quantity, $\mathrm{Y}$ country GDP, } \\
\hline \multicolumn{12}{|c|}{$\mathrm{Y} / \mathrm{L}=$ country GDP per worker. } \\
\hline & & & & & & & & & & & \\
\hline
\end{tabular}


Table 2. Economic Variables Components Descriptive Statistics by Humn Development Index (Reference U.S.)

\begin{tabular}{|c|c|c|c|c|c|c|c|c|c|}
\hline \multicolumn{10}{|c|}{ Panel A: Mean } \\
\hline & $\mathrm{n}$ & Overall & EM & IM & $P$ & $\mathrm{X}$ & $\mathrm{Y}$ & $\mathrm{L}$ & $\mathrm{Y} / \mathrm{L}$ \\
\hline High & 44 & 0.0965 & 0.4597 & 0.1411 & 0.8808 & 0.1572 & 0.0588 & 0.0882 & 0.5352 \\
\hline Middle & 54 & 0.0213 & 0.1829 & 0.0702 & 0.6738 & 0.1193 & 0.0237 & 0.2664 & 0.1634 \\
\hline Low & 28 & 0.0025 & 0.0504 & 0.0390 & 0.6691 & 0.0587 & 0.0015 & 0.0527 & 0.0355 \\
\hline All & 126 & 0.0434 & 0.2501 & 0.0880 & 0.7450 & 0.1191 & 0.0311 & 0.1567 & 0.2648 \\
\hline \multicolumn{10}{|c|}{ Panel B: CV } \\
\hline & $\mathrm{n}$ & Overall & EM & IM & $\mathrm{P}$ & $\mathrm{X}$ & $\mathrm{Y}$ & $\mathrm{L}$ & $\mathrm{Y} / \mathrm{L}$ \\
\hline High & 44 & 0.5276 & 1.6777 & 0.7407 & 2.9089 & 0.8567 & 0.3724 & 0.5020 & 2.6018 \\
\hline Middle & 54 & 0.4661 & 0.9698 & 1.0718 & 3.0297 & 0.8354 & 0.3792 & 0.2472 & 1.8653 \\
\hline Low & 28 & 0.5102 & 1.0633 & 0.9489 & 6.5406 & 1.0121 & 0.7500 & 0.6809 & 2.2188 \\
\hline All & 126 & 0.3670 & 0.9611 & 0.6887 & 2.9281 & 0.7977 & 0.2999 & 0.2186 & 1.0828 \\
\hline \multicolumn{10}{|c|}{ Note: $\mathrm{EM}=$ extensive margin, $\mathrm{IM}=$ intensive margin, $\mathrm{P}=$ price, $\mathrm{X}=$ quantity, $\mathrm{Y}=$ country GDP } \\
\hline \multicolumn{10}{|c|}{$\mathrm{L}=$ country employment, $\mathrm{Y} / \mathrm{L}=$ country GDP per worker. } \\
\hline \multicolumn{10}{|c|}{ Sources: Hummels \& Klenow (2005) } \\
\hline
\end{tabular}

Table 3. Economic Variables Components Descriptive Statistics by Region (Reference U.S.)

\begin{tabular}{|c|c|c|c|c|c|c|c|c|c|}
\hline \multicolumn{10}{|l|}{ Panel A: Mean } \\
\hline & $\mathrm{n}$ & Overall & EM & IM & $\mathrm{P}$ & $\mathrm{X}$ & $\mathrm{Y}$ & $\mathrm{L}$ & $\mathrm{Y} / \mathrm{L}$ \\
\hline $\begin{array}{l}\text { East Asia and } \\
\text { Pacific }\end{array}$ & 8 & 0.0695 & 0.3617 & 0.1338 & 0.6645 & 0.2479 & 0.0694 & 1.0623 & 0.1517 \\
\hline $\begin{array}{l}\text { Europe and Central } \\
\text { Asia }\end{array}$ & 9 & 0.0343 & 0.4174 & 0.0680 & 0.5602 & 0.1223 & 0.0242 & 0.1134 & 0.2088 \\
\hline $\begin{array}{l}\text { Latin America and } \\
\text { the Caribbean }\end{array}$ & 26 & 0.0185 & 0.1549 & 0.0702 & 0.6583 & 0.1056 & 0.0122 & 0.0473 & 0.2178 \\
\hline $\begin{array}{l}\text { Middle East and } \\
\text { North Africa }\end{array}$ & 7 & 0.0151 & 0.1962 & 0.0712 & 0.6628 & 0.1046 & 0.0110 & 0.0548 & 0.1953 \\
\hline South Asia & 5 & 0.0121 & 0.1792 & 0.0563 & 0.6113 & 0.1518 & 0.0510 & 0.7205 & 0.0818 \\
\hline Sub-Saharan Africa & 40 & 0.0033 & 0.0593 & 0.0405 & 0.7096 & 0.0586 & 0.0021 & 0.0431 & 0.0787 \\
\hline High OECD & 25 & 0.1422 & 0.5420 & 0.1895 & 1.0277 & 0.1854 & 0.0939 & 0.1270 & 0.6550 \\
\hline Other High Income & 6 & 0.0441 & 0.4412 & 0.0744 & 0.7714 & 0.1171 & 0.0106 & 0.0188 & 0.5518 \\
\hline All Countries & 126 & 0.0434 & 0.2501 & 0.0880 & 0.7450 & 0.1191 & 0.0311 & 0.1567 & 0.2648 \\
\hline \multicolumn{10}{|l|}{ Panel B: CV } \\
\hline & $\mathrm{n}$ & Overall & EM & IM & $\mathrm{P}$ & $\mathrm{X}$ & $\mathrm{Y}$ & $\mathrm{L}$ & $\mathrm{Y} / \mathrm{L}$ \\
\hline $\begin{array}{l}\text { East Asia and } \\
\text { Pacific }\end{array}$ & 8 & 0.6 & 1.2299 & 1.1799 & 4.5923 & 0.8455 & 99 & 0.4123 & 1.3841 \\
\hline $\begin{array}{l}\text { Europe and Central } \\
\text { Asia }\end{array}$ & 9 & 1.1100 & 2.3176 & 1.2274 & 7.3517 & 1.1782 & 0.6643 & 0.6718 & 2.9408 \\
\hline $\begin{array}{l}\text { Latin America and } \\
\text { the Caribbean }\end{array}$ & 26 & 0.5014 & 0.8707 & 1.2513 & 6.6428 & 1.2138 & 0.4652 & 0.5169 & 2.3394 \\
\hline $\begin{array}{l}\text { Middle East and } \\
\text { North Africa }\end{array}$ & 7 & 1.2177 & 1.6669 & 1.2088 & 5.6027 & 1.2512 & 0.9665 & 1.1161 & 2.7087 \\
\hline South Asia & 5 & 0.8231 & 1.0034 & 2.0252 & 8.2944 & 1.5553 & 0.5953 & 0.5560 & 3.1103 \\
\hline Sub-Saharan Africa & 40 & 0.4459 & 0.7772 & 1.0916 & 2.9395 & 1.1248 & 0.4236 & 0.6301 & 0.8275 \\
\hline High OECD & 25 & 0.6172 & 2.0247 & 0.7962 & 3.4052 & 0.8196 & 0.4611 & 0.5721 & 4.1614 \\
\hline Other High Income & 6 & 0.7917 & 2.1181 & 1.0027 & 2.9320 & 0.8566 & 0.8377 & 0.7737 & 4.4144 \\
\hline All Countries & 126 & 0.3670 & 0.9611 & 0.6887 & 2.9281 & 0.7977 & 0.2999 & 0.2186 & 1.0828 \\
\hline \multicolumn{10}{|c|}{ Note: $\mathrm{EM}=$ extensive margin, $\mathrm{IM}=$ intensive margin, $\mathrm{P}=$ price, $\mathrm{X}=$ quantity, $\mathrm{Y}$ country GDP } \\
\hline \multicolumn{10}{|c|}{$\mathrm{L}=$ country employment, $\mathrm{Y} / \mathrm{L}=$ country GDP per worker. } \\
\hline \multicolumn{10}{|c|}{ Sources: Hummels and Klenow (2005), World Bank (2007) and calculations by the authors } \\
\hline
\end{tabular}


Table 4. Economic Variables Components Descriptive Statistics by Income (Reference U.S.)

\begin{tabular}{|l|c|c|c|c|c|c|c|c|c|}
\hline Panel A: Mean & $\mathrm{n}$ & Overall & $\mathrm{EM}$ & $\mathrm{IM}$ & $\mathrm{P}$ & $\mathrm{X}$ & $\mathrm{Y}$ & $\mathrm{L}$ & $\mathrm{Y} / \mathrm{L}$ \\
\hline Low & 11 & 0.0035 & 0.0639 & 0.0439 & 0.6934 & 0.0718 & 0.0073 & 0.1282 & 0.0438 \\
\hline Middle & 34 & 0.0280 & 0.2401 & 0.0795 & 0.6375 & 0.1336 & 0.0295 & 0.3106 & 0.1793 \\
\hline Upper Middle & 20 & 0.0275 & 0.2269 & 0.0701 & 0.6725 & 0.1090 & 0.0099 & 0.0322 & 0.2893 \\
\hline High & 31 & 0.1232 & 0.5225 & 0.1672 & 0.9781 & 0.1722 & 0.0777 & 0.1061 & 0.6350 \\
\hline All & 126 & 0.0434 & 0.2501 & 0.0880 & 0.7450 & 0.1191 & 0.0311 & 0.1567 & 0.2648 \\
\hline Panel B: CV & $\mathrm{n}$ & Overall & $\mathrm{EM}$ & $\mathrm{IM}$ & $\mathrm{P}$ & $\mathrm{X}$ & $\mathrm{Y}$ & $\mathrm{L}$ & $\mathrm{Y} / \mathrm{L}$ \\
\hline \multicolumn{1}{|c|}{} \\
\hline Low & 41 & 0.5000 & 0.7821 & 1.1285 & 2.9506 & 1.0700 & 0.2303 & 0.2720 & 1.8029 \\
\hline Middle & 34 & 0.5224 & 1.2637 & 1.1103 & 4.8405 & 0.8227 & 0.4173 & 0.2456 & 2.7878 \\
\hline Upper Middle & 20 & 0.6125 & 0.8714 & 1.0868 & 7.1164 & 1.0552 & 0.5593 & 0.5629 & 4.4592 \\
\hline High & 31 & 0.5839 & 2.0307 & 0.7603 & 3.1736 & 0.8134 & 0.4195 & 0.5214 & 4.0875 \\
\hline All & 126 & 0.3670 & 0.9611 & 0.6887 & 2.9281 & 0.7977 & 0.2999 & 0.2186 & 1.0828 \\
\hline
\end{tabular}

Table 5. F-tests for Equality of Means of Economic Performance Components (Reference U.S.)

\begin{tabular}{|c|c|c|}
\hline Panel A: HDI & $\mathrm{F}$ & $\mathrm{p}$-value \\
\hline Overall & 7.83 & 0.001 \\
\hline EM & 39.41 & 0.000 \\
\hline IM & 6.99 & 0.001 \\
\hline $\mathrm{P}$ & 11.19 & 0.000 \\
\hline $\mathrm{X}$ & 3.90 & 0.023 \\
\hline $\mathrm{Y}$ & 2.95 & 0.056 \\
\hline $\mathrm{L}$ & 1.13 & 0.326 \\
\hline $\mathrm{Y} / \mathrm{L}$ & 144.45 & 0.000 \\
\hline Panel B: Region & F & p-value \\
\hline Overall & 4.09 & 0.000 \\
\hline EM & 18.56 & 0.000 \\
\hline IM & 3.91 & 0.001 \\
\hline $\mathrm{P}$ & 8.64 & 0.000 \\
\hline $\mathrm{X}$ & 2.83 & 0.009 \\
\hline $\mathrm{Y}$ & 2.30 & 0.031 \\
\hline $\mathrm{L}$ & 2.82 & 0.009 \\
\hline $\mathrm{Y} / \mathrm{L}$ & 73.11 & 0.000 \\
\hline Panel C: Income & $\mathrm{F}$ & $\mathrm{p}$-value \\
\hline Overall & 7.63 & 0.000 \\
\hline EM & 32.11 & 0.000 \\
\hline IM & 6.54 & 0.000 \\
\hline $\mathrm{P}$ & 16.06 & 0.000 \\
\hline $\mathrm{X}$ & 2.95 & 0.035 \\
\hline $\mathrm{Y}$ & 3.27 & 0.024 \\
\hline $\mathrm{L}$ & 0.79 & 0.500 \\
\hline $\mathrm{Y} / \mathrm{L}$ & 274.62 & 0.000 \\
\hline \multicolumn{3}{|c|}{ Note: $\mathrm{EM}=$ extensive margin, $\mathrm{IM}=$ intensive margin } \\
\hline \multicolumn{3}{|c|}{$\mathrm{P}=$ price, $\mathrm{X}=$ quantity, $\mathrm{Y}$ country DP } \\
\hline \multicolumn{3}{|c|}{$\mathrm{L}=$ country employment, $\mathrm{Y} / \mathrm{L}=$ country GDP per worker } \\
\hline \multicolumn{3}{|c|}{$\begin{array}{l}\text { Sources: Hummels and Klenow (2005), Human Development Report } \\
\text { (2007), World Bank (2007) and calculations by the authors }\end{array}$} \\
\hline
\end{tabular}

